MNSS. HS30.2:SM75

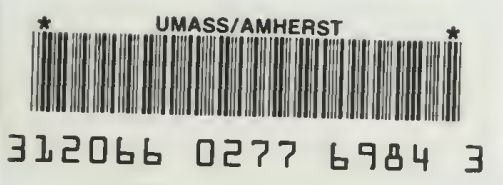

Smokeless Tobacco Advertising Expenditures

Before and After the

Smokeless Tobacco Master Settlement Agreement

A Report of the Massachusetts Department of Public Health

May 2002

$$
\begin{gathered}
\text { GOVERMENT DOCUMENTS } \\
\text { COLLECTION } \\
\text { APR } 2 \text { \& } 2003 \\
\text { University of MaSsachusetts } \\
\text { Depository CODy }
\end{gathered}
$$



$\because$ 


\section{Smokeless Tobacco Advertising Expenditures Before and After the Smokeless Tobacco Master Settlement Agreement}

On November 23, 1998, United States Smokeless Tobacco Company (USST) settled with 44 States' Attorneys Generals regarding smokeless tobacco-related health costs incurred by the states' Medicaid programs. USST was the only smokeless tobacco manufacturer to be sued as part of the Smokeless Tobacco Master Settlement Agreement (STMSA), and they were the only company to sign the settlement agreement. In addition to monetary payments to the states, the STMSA required the elimination of certain types of outdoor tobacco advertisements, including those found on billboards, in arenas, stadiums, shopping malls, and video arcades, and on private or public transit vehicles or waiting areas. The STMSA also forbade tobacco manufacturers from "directly or indirectly targeting youth in their promotional activities, or engaging in activities with the primary purpose of initiating, maintaining or increasing youth tobacco use." The provision is identical to that stipulated by the Master Settlement Agreement between the States' Attorney Generals and major cigarette ${ }^{2}$ manufacturers.

In 1995, the Food and Drug Administration proposed a rule on tobacco products prohibiting advertising in "youth" magazines with greater than $15 \%$ youth readers (age under 18) or two million plus youth readers. ${ }^{3}$ In response to complaints by the States' Attorneys Generals that advertising in youth magazines violated the MSA, Philip Morris curtailed cigarette advertising in magazines with $15 \%$ or more youth readers or two million plus youth readers in 1999 . Two other tobacco companies, Brown and Williamson and Lorillard, also agreed not to advertise in magazines with $15 \%$ or more youth readers and with $18 \%$ or more youth readers, respectively. ${ }^{45}$

${ }^{6}$ The purpose of this present study is to determine whether USST similarly stopped advertising in magazines with a significant number of youth readers after signing the STMSA. 



\section{Method}

To evaluate whether USST reduced advertising after the adoption of the STMSA, we compared smokeless tobacco advertising in the United States for each year from 1997 through 2001. The average, annual expenditures for two time periods, pre STMSA $(1997,1998)$ and post STMSA $(1999,2000,2001)$ are also compared. We also contrasted expenditures by USST with other manufacturers of smokeless tobacco who did not sign the SSMA, specifically Swisher, Conwood, and Swedish Match. This current analysis focuses on expenditures for advertising in all magazines with at least 15 percent youth readership or over two million youth readers.

\section{$\underline{\text { Data Sources }}$}

We obtained estimated annual cigarette expenditures for media advertising from Competitive Media Reporting (CMR), a commercial vendor that monitors advertisements in major magazines published in the United States. ${ }^{7}$ CMR estimates the dollars a company spends on advertising by obtaining published prices for advertisements, and multiplying those prices by the number of ads appearing in popular magazines. Youth and adult readership were estimated based on consumer surveys conducted by Simmons Market Research Bureau, Inc. (SMRB). ${ }^{1}$ In 1997, 1998, and 1999, twelve magazines met the criteria for youth readers that ran smokeless tobacco advertising. The number fell to nine for 2000 and 2001 as Field \& Stream, Popular Science and Outdoor Life were reclassified as adult magazines. Because the nature of the readership changed from 19972001 , these three magazines have been excluded from the youth analyses, and advertisements in these magazines are calculated separately. All other magazines maintained their classification as

\footnotetext{
${ }^{1}$ For the year 1997, the 1996 Simmons Teen-Age Research (STARS) and 1996 Simmons Fall SMM were used to determine whether the magazine was in the youth or adult category. For the years 1998 and 1999, the 1998 STARS/Prizm and the 1998 Simmons Spring SMM/Prizm reports were used to categorize the magazines. For the year 2000, the Simmons NCS Teens Fall 2000 and full year Prizm reports were used. For 2001, the Simmons NCS Teens Spring 2001/Prizm and Simmons Spring 2001 NCS, full year Prizm reports were used.
} 


\section{Digitized by the Internet Archive in 2014}


either adult or youth from 1997 through 2001. The nine magazines that were consistently rated as "youth" magazines are listed in Appendix A.

\section{$\underline{\text { Results }}$}

As detailed in Table 1, overall smokeless tobacco magazine advertising expenditures rose from \$9.4 million to \$24 million from 1997 to 2001 , a $150 \%$ increase. For USST, expenditures increased from \$6.9 million to $\$ 16.2$ million, a $135 \%$ increase.

\begin{tabular}{|c|c|c|c|c|c|}
\hline & 1997 & 1998 & 1999 & 2000 & 2001 \\
\hline \multicolumn{6}{|l|}{ USST } \\
\hline Youth & $\$ 3,585$ & $\$ 7,245$ & $\$ 6,366$ & $\$ 2,631$ & $\$ 9,374$ \\
\hline Other & 3,303 & 6,140 & 7,297 & 7,966 & 6,872 \\
\hline Sub Total & 6,888 & 13,384 & 13,663 & 10,598 & 16,246 \\
\hline \multicolumn{6}{|l|}{ Swisher } \\
\hline Youth & $\$ 1,057$ & $\$ 910$ & $\$ 853$ & $\$ 1,016$ & $\$ 955$ \\
\hline Other & 1,036 & 872 & 1,474 & 1,350 & 1,557 \\
\hline Sub Total & 2,093 & 1,782 & 2,327 & 2,366 & 2,512 \\
\hline \multicolumn{6}{|l|}{ Conwood } \\
\hline Youth & $\$ 0$ & $\$ 91$ & $\$ 257$ & $\$ 176$ & $\$ 0$ \\
\hline Other & 0 & 222 & 541 & 686 & 882 \\
\hline Sub Total & 0 & 313 & 798 & 862 & 882 \\
\hline \multicolumn{6}{|c|}{ Swedish Match } \\
\hline Youth & $\$ 129$ & $\$ 1,939$ & $\$ 765$ & $\$ 706$ & $\$ 776$ \\
\hline Other & 273 & 1,311 & 1,945 & 1,484 & 3,558 \\
\hline Sub Total & 402 & 3,250 & 2,710 & 2,190 & 4,333 \\
\hline \multicolumn{6}{|l|}{ ALL } \\
\hline Youth & $\$ 4,771$ & $\$ 10,184$ & $\$ 8,240$ & $\$ 4,529$ & $\$ 11,104$ \\
\hline Other & 4,611 & 8,543 & 11,287 & 11,486 & 12,868 \\
\hline Total & $\$ 9,382$ & $\$ 18,727$ & $\$ 19,527$ & $\$ 16,015$ & $\$ 23,972$ \\
\hline
\end{tabular}



Most importantly, youth magazine advertising also rose, from $\$ 4.7$ million in 1997 to $\$ 11.1$ million in 2001 for all companies. This figure reflects a $136 \%$ increase in advertising expenditures. For USST, the increase from 1997 to 2001 was $161 \%$, from $\$ 3.6$ million to $\$ 9.4$ million. As Table 2 indicates, USST continued to allocate a substantial proportion of their advertising dollars to youth magazines. Despite their signing of the STMSA, USST increased their advertisements in youth magazines $13 \%$, from an average of \$5.4 million dollars in the preSTMSA period to an average of $\$ 6.1$ million dollars in the post-STMSA period. In the period from 1999-2001, USST placed close to half (45\%) their smokeless tobacco advertising dollars in magazines that were read by a substantial number of adolescents. This $45 \%$ is only slightly lower than the Pre-STMSA percentage of 53\%. The increase in advertising dollars spent in youth magazines by USST is in marked contrast to the three other smokeless tobacco companies that decreased by $11 \%$ their overall spending in youth magazines. Swisher, Conwood, and Swedish Match decreased their advertising of smokeless tobacco in youth-oriented magazines from an average of $\$ 2,063$ million dollars in the pre-STMSA period to $\$ 1,834$ million dollars in the postSTMSA period. Additionally these three companies decreased the percentage of their budget (from $53 \%$ to $29 \%$ ) that was devoted to advertisements in magazines with a substantial youth readership. 



\begin{tabular}{|c|c|c|c|c|}
\hline \multicolumn{5}{|c|}{$\begin{array}{l}\text { Table 2: Smokeless Tobacco Magazine Advertising } \\
\text { Pre-Post the STMSA by Youth and Adult Magazines } \\
\text { Average Annual Expenditures (in millions of dollars) }\end{array}$} \\
\hline & $\begin{array}{l}\text { Pre } \\
\text { 97-98 } \\
\text { Average }\end{array}$ & $\begin{array}{l}\text { MA } \\
\% \text { of } \\
\text { expenditures }\end{array}$ & $\begin{array}{c}\text { Post } \\
\text { 99-01 } \\
\text { Average }\end{array}$ & $\begin{array}{l}\text { TSMA } \\
\% \text { of } \\
\text { expenditures }\end{array}$ \\
\hline $\begin{array}{l}\text { USST } \\
\text { Youth } \\
\text { Other } \\
\text { Subtotal }\end{array}$ & $\begin{array}{c}\$ 5,415 \\
4,721 \\
\$ 10,135\end{array}$ & $\begin{array}{l}53 \% \\
47 \%\end{array}$ & $\begin{array}{r}\$ 6,123 \\
7,378 \\
\$ 13,501\end{array}$ & $\begin{array}{l}45 \% \\
55 \%\end{array}$ \\
\hline $\begin{array}{l}\text { Swisher, } \\
\text { Youth } \\
\text { Other } \\
\text { Subtotal }\end{array}$ & $\begin{array}{c}\$ 2,063 \\
1,857 \\
3,920\end{array}$ & $\begin{array}{l}\text { Match Com } \\
53 \% \\
47 \%\end{array}$ & $\begin{array}{r}\text { Totals } \\
\$ 1,834 \\
4,492 \\
6,326\end{array}$ & $\begin{array}{l}29 \% \\
71 \%\end{array}$ \\
\hline $\begin{array}{l}\text { All Com } \\
\text { Youth } \\
\text { Other } \\
\text { Total }\end{array}$ & $\begin{array}{r}\$ 7,478 \\
6,578 \\
\$ 14,056\end{array}$ & $\begin{array}{l}53 \% \\
47 \%\end{array}$ & $\begin{array}{r}\$ 7,957 \\
11,870 \\
\$ 19,827\end{array}$ & $\begin{array}{l}40 \% \\
60 \%\end{array}$ \\
\hline
\end{tabular}

Data from Table 3 indicates the amount of advertising, for both USST and the three remaining smokeless tobacco companies, for the periods before and after the STSMA. During the postsettlement period, USST paid Sports Illustrated an average of \$2.5 million each year for advertising its brands. In addition, USST paid Rolling Stone magazine $\$ 937,000$, Motor Trend

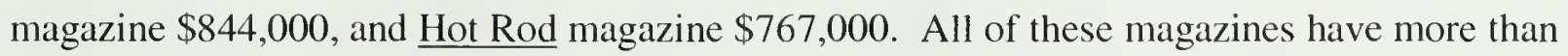
twenty-percent youth readership and more than two million plus youth readers. Data from Table 4 enumerates both the percent of youth readers for each of the nine youth magazines and the number of youth readers exposed to smokeless tobacco advertisements. Twenty-three percent of 

the readers of Sports Illustrated are adolescents between the age of 12-17; that is, 7.2 million adolescents are exposed to USST smokeless tobacco advertisements. Similarly, Rolling Stone, with a $28 \%$ youth readership, is read by 3.3 million adolescents; Motor Trend, with a $25 \%$ youth readership, is read by 2.1 million adolescent readers; and Hot Rod , with a $31 \%$ youth readership, is read by 2.9 million adolescent readers. These figures demonstrate that USST's smokeless tobacco advertisements continued to reach a significant number of adolescents.

Table 3: Smokeless Tobacco Average Annual Youth magazine Advertising Expenditures Pre/Post the STMSA for USST and Other Companies

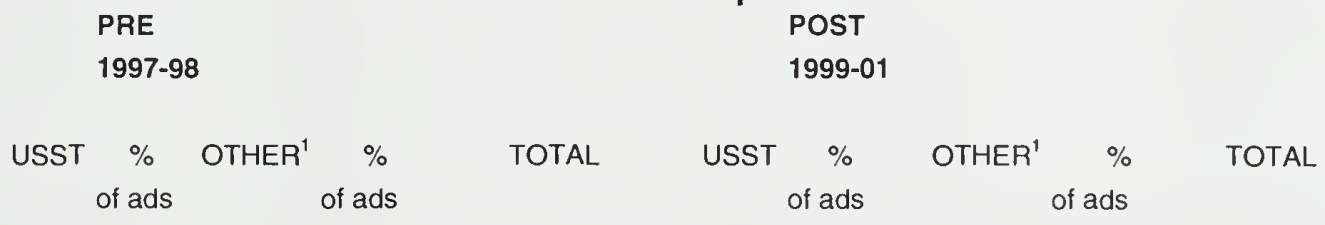

$\begin{array}{lrrrrrrrrrr}\text { Sports Illustrated } & \$ 2,759 & 72 \% & \$ 1,076 & 28 \% & \$ 3,835 & \$ 2,486 & 74 \% & \$ 871 & 26 \% & \$ 3,357 \\ \text { Hot Rod } & 323 & 44 \% & 407 & 56 \% & 730 & 767 & 69 \% & 345 & 31 \% & 1112 \\ \text { Rolling Stone } & 810 & 79 \% & 211 & 21 \% & 1021 & 937 & 100 \% & 0 & 0 \% & 937 \\ \text { Motor Trend } & 188 & 100 \% & 0 & 0 \% & 188 & 844 & 94 \% & 55 & 6 \% & 899 \\ \text { Sporting News } & 491 & 76 \% & 159 & 24 \% & 650 & 435 & 49 \% & 449 & 51 \% & 884 \\ \text { Sport } & 273 & 57 \% & 296 & 61 \% & 482 & 293 & 78 \% & 83 & 22 \% & 376 \\ \text { TV Guide } & 167 & 100 \% & 0 & 0 \% & 167 & 258 & 100 \% & 0 & 0 \% & 258 \\ \text { Popular Science } & 347 & 100 \% & 0 & 0 \% & 347 & 92 & 100 \% & 0 & 0 \% & 92 \\ \text { Spin } & 58 & 100 \% & 0 & 0 \% & 58 & 13 & 30 \% & 31 & 70 \% & 44 \\ & & & & & & & & & & \end{array}$

\footnotetext{
${ }^{1}$ OTHER $=$ Swisher, Conwood, Swedish Match combined advertisements
} 

Table 4: Percentage and Number of Youth Readers for Major Youth Magazines

$\begin{array}{cl}\text { \%Youth } & \text { Youth } \\ \text { Readers } & \text { Readers } \\ \text { (1998) } & \text { (in 000's) }\end{array}$

$\begin{array}{lcc}\text { Sports Illustrated } & 23 \% & 7,254 \\ \text { Hot Rod } & 31 \% & 2,937 \\ \text { Rolling Stone } & 28 \% & 3,318 \\ \text { Motor Trend } & 25 \% & 2,131 \\ \text { Sporting News } & 30 \% & 1,190 \\ \text { Sport } & 33 \% & 2,605 \\ \text { TV Guide } & 16 \% & 8,131 \\ \text { Popular Science } & 30 \% & 2,559 \\ \text { Spin } & 32 \% & 1,316 \\ \text { Total } & & 31,441\end{array}$

\section{Conclusion}

Despite the restrictions placed on youth advertising by the STMSA, USST continues to heavily advertise in youth-oriented magazines. Expenditures on youth advertising actually increased after the STMSA, and expenditures remain high. Although USST was the only signatory to the STMSA, the company continued to heavily advertise their brands in magazines popular with youth. This is in sharp contract to the actions of the three major cigarette manufacturers who curtailed advertising in youth magazines in 1999, one year after signing the MSA, and to smokeless tobacco companies who did not sign the STMSA . 

Appendix A

Magazines consistently rated as Youth from 1997-2001.

Sports Illustrated

Hot Rod

Rolling Stone

Motor Trend

Sporting News

Sport

TV Guide

Popular Science

Spin 

${ }^{1}$ Smokeless Tobacco Master Settlement Agreement. November, 1998: 16 Provision III Permanent Relief (a) Prohibition in Youth Targeting.

${ }^{2}$ Master Settlement Agreement. November, 1998: 18-19 Provision III Permanent Relief (a) Prohibition on Youth Targeting.

${ }^{3} 21$ CFR Post 801 et al. Regulation Restricting the Sale and Distribution of Cigarettes and Smokeless Tobacco Products to Protect Children and Adolescents: Proposed Rule. Federal Register, August 11, 1995.

${ }^{4}$ Orlowsky, M. to Gregoire, C., Letter. Lorillard Tobacco Company, Greensboro, N.C., February 9, 2001.

${ }^{5}$ Szymanczyk, M.F. to Gregoire, C. Letter. Philip Morris USA, New York, June 2, 2000.

${ }^{6}$ Fisher, M.F., to Gregoire, C. Letter. Brown \& Williamson Tobacco, Louisville, KY, November $28,2000$.

${ }^{7}$ Federal Trade Commission Report to Congress for the Years 1998 and 1999 Pursuant to the Comprehensive Smokeless Tobacco Health Education Account of 1986. Federal Trade Commission, Washington, D.C. 2001.

Simmons Market Research Bureau, Inc.

("Simmons") confirms that it provided the databases used by Arnold Worldwide Partners ("Arnold") for compilation of its report, pursuant to a License Agreement between Simmons and Arnold. Simmons makes no representations or warranties regarding use of the data by Arnold, other than to confirm that Simmons data was employed in the compilation.

CMR, L. L. C. ascertains that it provided data used by Arnold Worldwide Partners in developing this report, pursuant to the License Agreement that exists between CMR, L.L.C. and Arnold. CMR, L.L.C. makes not representations or warranties regarding use of CMR information by Arnold, other than to confirm that CMR data was employed in the development of this report. 
